\title{
ANALYSIS OF HEAVY METALS IN SOIL FROM BURNT COMPUTER BUSINESS CENTER
}

A. A. ADAMU

\begin{abstract}
Deliberate or accidental burning of materials containing heavy metals such as electronic components may result in serious environmental pollution. Burning of these materials is common in open waste dumps and sometimes during fire disasters. This paper looked at the determination of heavy metal concentration in soil samples at burnt computer business centre (A case study of PTI, Effurun). Soil samples were collected from the site and another sample from unaffected area as control. The samples were analyzed for the presence of copper, zinc, cadmium, lead and mercury using GBC Scientific AAS GF 3000. The result of the analysis shows that the concentrations of the heavy metals at the site are much higher than the control sample. The mean concentration of copper is $0.284 \mathrm{ppm}$ which is more than $2400 \%$ higher than the control sample's concentration of $0.011 \mathrm{ppm}$, lead $2.749 \mathrm{ppm}$ higher by 50 $\%$, cadmium 0.058 ppm higher by $222 \%$, and zinc 1.626 ppm higher by $80 \%$.
\end{abstract}

Though the concentrations of the heavy metals analyzed are much higher than that of the control sample, yet they are less than the maximum permissible limits by World Health Organization (WHO) for soil except cadmium in samples $C$ and $E(0.09 \mathrm{ppm}$ each) which is higher than the WHO maximum permissible limits of $0.06 \mathrm{ppm}$.

Based on the results obtained, it can be concluded that there is an increase in concentration of heavy metals in the burnt computer business centre.

KEYWORDS: Heavy metals, burnt computer center, soil, pollution.

\section{INTRODUCTION}

Fire disasters are common in Nigeria particularly in markets and offices, apart from destruction of properties and sometimes lost of lives, the burning causes heavy pollution. The major types of pollution caused by fire disaster include air, land, thermal and noise pollution. The types of pollutants present in a burnt place may depends on the materials burned, for example, the pollutants produced from burning textiles materials may be different from those from electronic devices which may contain substantial amount of heavy metals. A computer business center comprises of computers, photocopiers, scanners, printers etc, these machines are made up of electrical and electronic components that contains heavy metals such as lead, cadmium, mercury, nickel, Zinc, copper, arsenic and mercury. On burning, the heavy metals in pure form or in form of oxides may contaminate the soil and may leach into the underground water aquifer and pollute the underground water. Air borne pollutants from fire hazard sometimes come back to land by means of deposition; acid rains etc which in turn cause land pollution. Heavy metals may also come from natural and anthropogenic sources and the natural levels of heavy metals in the environment had never been a threat to health (Des, 2005; Enger\& Smith, 2004).

Humans have no mechanism to excrete

A. A. Adamu, Petroleum \& Natural Gas Processing Department, Petroleum Training Institute Effurun, Delta State, Nigeria. 
heavy metals or metabolize them further; trace levels consumed over time gradually accumulate in the body and may sooner or later produce toxic effects (Bernard \& Richard, 1993).

Burnt sites are seldom analyzed in Nigeria; as such there is no data available on level of pollution cause by fire disasters. The aim of this study is to determine the concentration of some heavy metals in a burnt computer business center at Petroleum Training Institute (P.T.I) Effurun, Delta State.

\section{HEAVY METALS AND THEIR EFFECTS}

Heavy metals are toxic to human beings, animals and plants; they exist in soil, water and air in form of inorganic or organic compounds. Their major sources include; industrial discharge and improper disposal of solid waste such as electronic devices. Heavy Metals are dangerous to the human health because they tend to bioaccumulate. The effect of toxic metals such as mercury, arsenic, lead and cadmium are well known and available in literature (Ming-Ho, 2001; Wayne \& Ming-Ho, 2004; Enger\& Smith, 2004). The following are some of the effect of the heavy metals being considered in this study;

Lead; Acute lead poisoning in humans causes severe dysfunction in the kidneys, reproductive system, liver and the brain and central nervous system. It inhibits blood cells formation, causes difficulty in breathing, lung damage, and diseases such as asthma, bronchitis, and pneumonia, damage the immune system, interfering with cell maturation and skeletal growth, causes miscarriage, abortions, and stillbirths. In severe cases of heavy metals poisoning, coma and death may occur.

Mercury; Mercury is the only metal that is liquid at ambient temperature. It occurs in two forms, organic and inorganic form. While the inorganic form is toxic, the organic mercury is more toxic.It results in brain damage, chronic fatigue, severe disturbances in the kidney and liver.

Cadmium; Cadmium adversely affects several important enzymes in humans; it can also cause painful osteomalacia (bone disease), kidney damage, destruction of testicular tissue, and destruction of red blood cells.

Copper and Zinc;These are essential elements required in the body to maintain metabolism, but their accumulation beyond the threshold limits causes toxic effect, such as acute gastroenteritis characterized by nausea, vomiting, and diarrhea.

\section{BIOACCUMULATION} BIOMAGNIFICATION

AND

Some animals are able to excrete high proportions of abnormal heavy metal intake. Nevertheless, there is an upper limit to the amount of heavy metals that can be excreted by animals, above which there is accumulation in the body tissues. Heavy metals are hazardous as it has the tendency to accumulate in organisms. The small amount of harmless chemicals retain in the body over a long period of time may reach toxic level because of accumulation. This is referred to as bioaccumulation. The accumulation of the heavy metals may be compounded through food chain making the concentration thousands times higher than the concentration present in the environment. This multiplying effect that occurs through a food chain is called biomagnification. Biomagnification occurs because of the biomass pyramid. Through food chains, organisms at the top of the pyramid receive more concentrated heavy metals from the large biomass at the bottom of the food pyramid (Bernard \& Richard, 1993).

\section{EXPERIMENTAL PROCEDURE}

\section{Equipment, Materials and Reagent}

The following equipment, materials and reagents were used for the experimental work; Soil auger , Hot plate, Oven, Measuring cylinder, Filter paper, Conical flask, Beakers, Distilled water, Containers, Funnel, Thermometer, Wash bottle , pH meter, Sulphuric acid, Nitric acid, Perchloric acid, Atomic absorption spectrometer (GBC Scientific AAS GF 3000).

\section{Soil Sampling Procedure}

Soil samples at five locations within the burnt site and one sample $100 \mathrm{~m}$ away from the burnt site (to serve as a control) were collected at a depth of $15 \mathrm{~cm}$ using soil auger and following standard sampling procedure (Maria \&Csaba, 2002). The samples obtained were quickly transferred into clean sampling containers.

\section{Digestion of the Soil samples}

The digestion of the soil samples was done using ASTM D4309-12 method. The soil samples were 
oven dried at $105^{\circ} \mathrm{C}$ for $24 \mathrm{~h}$, followed by grinding and sieving using $0.18 \mathrm{~mm}$ sieve. $1.0 \mathrm{~g}$ of dry soil sample was accurately weighed and transferred to a $250 \mathrm{ml}$ conical flask. A measured volume of well-mixed acids, perchloric acid, nitric acid and sulphuric acid in the ratio of 1:2:2 was transferred into the flask containing the soil sample in the fume hood. The mixture was heated for about 20 minute on the hot plate until white fumes were observed. Digestion was stopped and the content was cooled. After cooling, $20 \mathrm{ml}$ of distilled water was added and boiled to bring the metal into solution. It was allowed for further cooling and filtered through Whatman 42 filter paper in a 100 $\mathrm{ml}$ volumetric flask and made to mark with distilled water. Then it was transferred into a 100 $\mathrm{ml}$ plastic can for AAS analysis. The concentrations of $\mathrm{Cu}, \mathrm{Zn}, \mathrm{Cd}, \mathrm{Pb}$, and $\mathrm{Hg}$ in the filtrate were determined by atomic absorption spectrometer, GBC Scientific AAS GF 3000 following standard method for determination of metals by atomic absorption spectrometry ASS (ASTM D1971-11).

\section{RESULTS AND DISCUSSION}

Results; Experimental result for the samples of the soil at burnt computer business centre compared with the World Health Organization (WHO) standard for soils is presented in Table 1. The mean concentrations of the samples are shown in Table2. Figure 1 and 2 shows the comparison between the samples mean concentrations and the control sample.

Table 1: Concentration of heavy metals in the soil samples at the burnt computer business centre.

\begin{tabular}{|c|c|c|c|c|c|c|c|c|}
\hline \multirow[b]{2}{*}{$\mathbf{S} / \mathbf{N}$} & \multirow[b]{2}{*}{ Heavy metal } & \multicolumn{6}{|c|}{ Sample/Concentration (ppm) } & \multirow{2}{*}{$\begin{array}{l}\text { WHO's } \\
\text { maximum } \\
\text { permissible } \\
\text { limit (ppm) }\end{array}$} \\
\hline & & A & B & C & D & $\mathbf{E}$ & Control & \\
\hline 1 & Copper, Cu & 0.152 & 0.101 & 0.463 & 0.661 & 0.042 & 0.011 & 20.000 \\
\hline 2 & Zinc, Zn & 0.727 & 1.848 & 0.966 & 3.621 & 0.966 & 0.897 & 5.000 \\
\hline 3 & Cadmium, Cd & 0.045 & 0.024 & 0.090 & 0.039 & 0.090 & 0.018 & 0.060 \\
\hline 4 & Lead, Pb & 2.660 & 2.075 & 3.621 & 2.314 & 3.077 & 1.823 & 10.000 \\
\hline 5 & Mercury, $\mathrm{Hg}$ & $<0.001$ & $<0.001$ & $<0.001$ & $<0.001$ & $<0.001$ & $<0.001$ & 0.030 \\
\hline
\end{tabular}

Table 2: Mean concentration of heavy metals at burnt computer business centre, PTI, Effurun

\begin{tabular}{|c|c|c|c|c|c|}
\hline $\mathrm{S} / \mathrm{N}$ & Heavy metal & $\begin{array}{l}\text { Mean Conc. of } \\
\text { Samples (ppm) } \\
X\end{array}$ & $\begin{array}{l}\text { Conc. of control } \\
\text { Sample } \\
\text { y }\end{array}$ & $\begin{array}{l}\text { WHO's Max. } \\
\text { Permissible } \\
\text { Limit (ppm) }\end{array}$ & $\begin{array}{l}\% \text { Increase ir } \\
\text { Conc. } \\
\quad=\frac{x-y}{y} \times 100\end{array}$ \\
\hline 1 & Copper, Cu & 0.284 & 0.011 & 20 & 2481.82 \\
\hline 2 & Zinc, Zn & 1.626 & 0.897 & 5 & 81.27 \\
\hline 3 & Cadmium, Cd & 0.058 & 0.018 & 0.06 & 222.22 \\
\hline 4 & Lead, Pb & 2.749 & 1.823 & 10 & 50.79 \\
\hline 5 & Mercury, $\mathrm{Hg}$ & $<0.001$ & $<0.001$ & 0.03 & \\
\hline
\end{tabular}




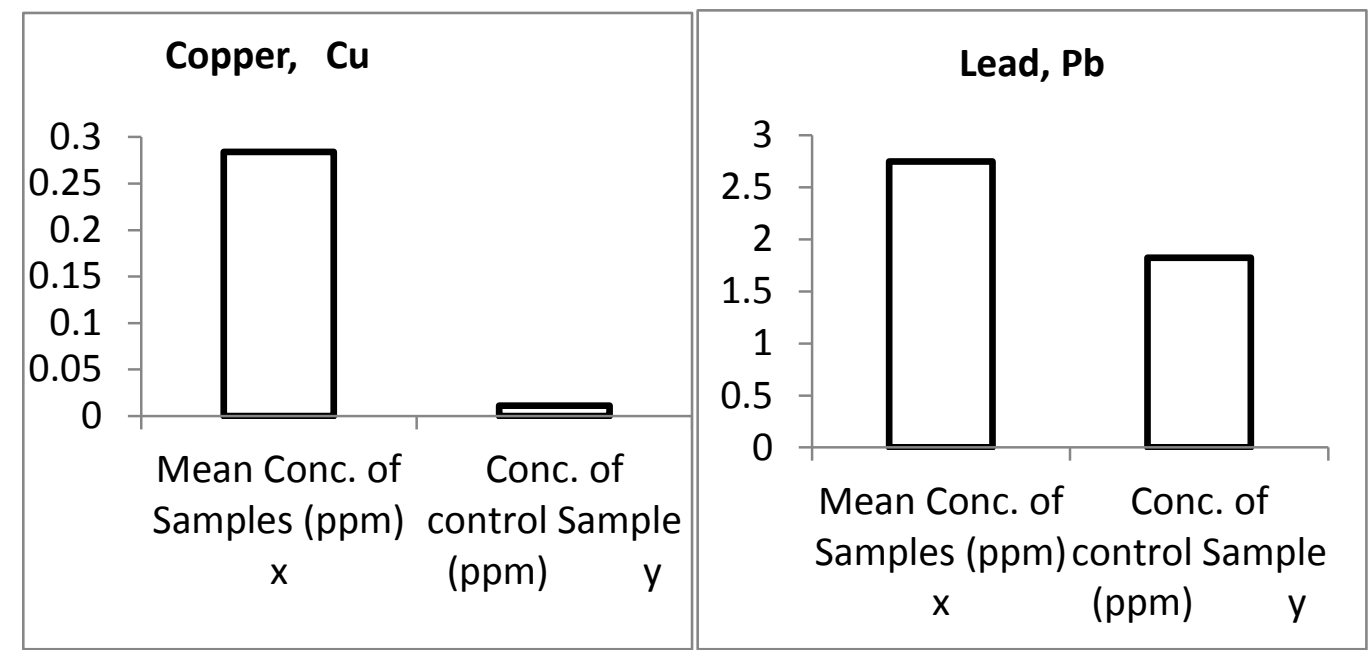

Figure 1: Mean concentration compared with control sample for copper and lead

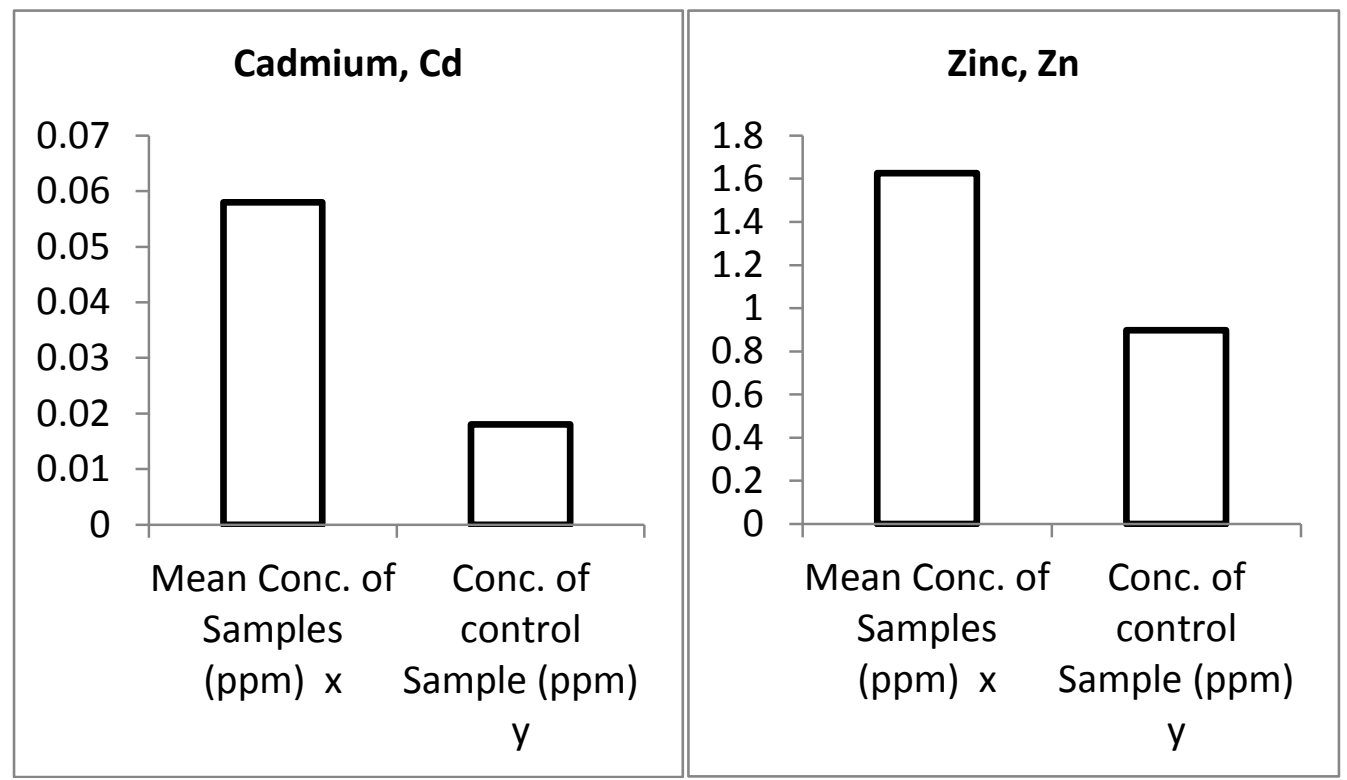

Figure 2: Mean concentrations compared with control sample for cadmium and zinc

\section{DISCUSSION OF RESULTS}

Table 1 and Table 2 shows the various concentrations of the heavy metals analysed. In all the samples analyzed the concentrations of the heavy metals are below the WHO limits except for cadmium in samples $\mathrm{C}$ and $\mathrm{E}$. However, these heavy metals are present at much higher concentrations when compared to the control sample. This results shows that there is a tremendous increase in the concentration of heavy metals ranging from 50 to about $2500 \%$ in this burnt computer business center, despite the time lag of about three years between the fire incidence and the time of this analysis. 


\section{CONCLUSION}

There is a tremendous increase in heavy metals concentration in the burnt computer business center. Though, concentrations of heavy metals below WHO's maximum permissible limits may not cause harmful effect on humans, animals and plants but the effect of bioaccumulation is of great concern.

\section{REFERENCES}

Bernard J. N and Richard, T. W., 1993. Environmental Science, 4th Edition, Prentice Hall, New Jersey.

Des W. C., 2005.Basic Concepts of Environmental Chemistry, 2nd Edition, CRC Press, Bola Raton FL, USA.
Enger E. D and Smith B. F., 2004. Environmental Science; A Study of Interrelationship, 9th edition, McGraw-Hill Higher Education, New York.

Maria, C and Csaba, C., 2002.Environmental Samplings and Analysis for Metals, Lewis Publishers, Bola Raton, Florida USA.

Ming-Ho, Y., 2001, Environmental Toxicology Impacts of Environmental Toxicants on Living Systems, Lewis Publishers, Florida, USA.

Wayne, G. L and Ming-Ho.Y., 2004.Introduction of Environmental Toxicology (Impacts of Chemicals upon Ecological Systems), 3rd Edition, Lewis Publishers, and New York. hh 